\title{
ANALISIS PENERAPAN KETENTUAN PERPAJAKAN ATAS PERBANDINGAN HUTANG DAN MODAL DI INDONESIA ${ }^{1}$
}

\author{
Ginda Togatorop*, Maria R.U.D. Tambunan \\ Program Pasca Sarjana Fakultas Ilmu Administrasi Universitas Indonesia \\ Jl. Pegangsaan Timur No. 16, Jakarta \\ ginda.simakui@gmail.com
}

\begin{abstract}
This article discusses the implementation of tax rules on debt-to-equity ratio in Indonesia. One of prolific profit shifting to minimize tax obligation performed by MNEs is through injecting huge amount of debt including debt from related parties as the equity. Therefore, the tax bases erosion exists due to excessive payment of interest calculated as deductible expenses against taxable income. This research occupies qualitative research, the data was collected through desk study and interview. The research shows that the implementation of this rule is a moving forward on Indonesia taxation system. However, it remainds task, such as the question whereas the ratio has been the reflection of business' equity structure. In addition, it needs to further scrutinize that each industries demand specific equity structure.
\end{abstract}

Keywords: Debt-to-Equity Ratio; Transfer Pricing; Profit Shifting; Tax Base Erosion; Arm's Lenght Principle

\begin{abstract}
Abstrak
Artikel ini membahas penerapan ketentuan perpajakan terkait perbandingan hutang dan modal ratio di Indonesia sebagai salah satu bentuk pengalihan laba untuk minimalisir beban pajak oleh perusahaan multi nasional dengan melakukan pinjaman jumlah besar kepada pihak afiliasi sebagai modal usaha. Akibatnya, terjadi penggerusan basis pemajakan di Indonesia dengan pembayaran bunga dengan jumlah yang tidak rasional untuk mengurangi penghasilan neto. Penelitian ini menggunakan metode penelitian kualitatif dengan teknik pengumpulan data kualitatif. Hasil penelitian menunjukkan bahwa ketentuan yang diterapkan saat ini merupakan salah satu langkah maju dalam mencegah terjadinya erosi basis pemajakan, yaitu menetapkan rasio utang terhadap modal sebesar 4:1. Namun, ketentuan tersebut masih menyisakan pekerjaan rumah seperti apakah rasio demikian benar-benar mampu mencerminkan struktur permodalan suatu entitas bisnis dimana setiap sektor industri memiliki karakteristik struktur permodalannya masing-masing.
\end{abstract}

Kata Kunci: Perbandingan Utang dan Modal; Transfer Pricing; Penggeseran Laba; Erosi Basis Pemajakan, Prinsip Kewajaran

\footnotetext{
${ }^{1}$ Merupakan artikel hasil penelitian.
} 


\section{A. Pendahuluan}

Praktik perencanaan pajak anak perusahaan multinasional melalui pendanaan atas hutang (debt) yang lebih tinggi terutama yang diperoleh dari entitas afiliasi dibandingkan dengan modal (ekuitas) untuk menjalankan kegiatan usaha mengakibatkan pembebanan bunga pinjaman yang besar. Atas pinjaman yang lebih besar dari modal tersebut, maka sebagai konsekuensinya, akan terjadi pembayaran bunga yang cukup besar. Pembebanan bunga yang lebih besar akan menggerus (erosi) basis pajak anak perusahaan yang berlokasi di negara yang tarif pajak lebih tinggi terutama ketika melakukan pinjaman ke pemberi pinjaman yang berlokasi di negara tarif pajak korporasinya lebih rendah. Pembayaran bunga yang berlebihan ke induk perusahaan di negara yang tarif pajak lebih rendah merupakan salah satu bentuk pengalihan laba (profit shifting) sehingga beban pajak untuk perusahaan grup secara global semakin kecil. Ketentuan perpajakan internasional dalam rangka menangkal praktik penghindaran pajak melalui skema pengerusan modal dan peningkatan hutang disebut thin capitalizasion rules.

Dalam konteks sistem perpajakan Indonesia terkait thin capitalization rule, Peraturan Menteri Keuangan Republik Indonesia Nomor 169/PMK.010/2015 (selanjutnya PMK-169) mengenai penentuan besarnya perbandingan antara utang dan modal perusahaan untuk keperluan perhitungan pajak penghasilan yang dirilis tanggal 9 September 2015 memberikan kepastian hukum pembatasan utang sesuai Pasal 18 ayat (1) UU Pajak Penghasilan. Peraturan ini mengisi kekosongan hukum selama 30 tahun, sejak Keputusan Menteri Keuangan Nomor 1002/KMK.04/1984 tentang Penentuan Perbandingan Utang dan Modal Sendiri untuk Keperluan Pengenaan Pajak Penghasilan dan Keputusan Menteri Keuangan Nomor 254/KMK.01/1985 tentang Penundaan Pelaksanaan Keputusan Menteri Keuangan Nomor 1002/KMK.04/1984 tentang Penentuan
Perbandingan Utang dan Modal Sendiri untuk Keperluan Pengenaan Pajak Penghasilan diterbitkan.

Pengaturan ini timbul akibat perlakuan pajak yang berbeda antara hasil/imbal balik dari pembiayaan melalui utang (bunga) dan modal (dividen) yang kemudian menciptakan dampak perlakuan berbeda dalam keputusan pembiayaan atau sering disebut debt bias (Fatica, Hemmelgarn, \& Nicodeme, 2012). Pembiayaan melalui utang lebih "menarik" karena mengurangi beban pajak dan sebagai konsekuensinya menghasilkan cost of capital yang rendah, terlebih jika dikaitkan dengan konsep weighted average cost of capital (Blessing, 2012). Peluang tersebut dimanfaatkan oleh perusahaan multinasional yang memiliki entitas anggota di lebih dari satu negara melalui apa yang disebut sebagai cross border financing (Masui, 2014) dengan skema pinjaman internal, penyaluran modal melalui skema pinjaman via pihak ketiga (back to back loan) atau dengan berbagai skema pinjaman lainnya (Piltz, 1996).

Debt bias tersebut mengakibatkan adanya penggerusan penghasilan kena pajak yang akan berpengaruh pada penghasilan neto perusahaan dan pada akhirnya berpengaruh pada penerimaan pajak dari Pajak Penghasilan (PPh) Badan (Blessing, 2012). Selain itu, praktik perencanaan pajak agresif untuk meminimalisir beban pajak, dengan menggunakan utang yang lebih sebagai modal usaha, pembiayaan dengn utang juga dapat menciptakan risiko makroekonomi, seperti kebangkrutan ataupun melemahnya nilai tukar.

Kini, banyak negara telah menerapkan ketentuan pajak domestik yang bertujuan untuk menangkal tingginya utang yang berlebihan. Upaya yang sejenis juga telah dilakukan oleh pemerintah Indonesia dalam mengatasi besarnya potensi pajak yang hilang akibat praktik tersebut. Upaya dalam menangkal tingginya tingkat utang tersebut dikenal dengan interest limitation rules. Peraturan tersebut pada umumnya memberikan kewenangan kepada otoritas pajak untuk mereklasifikasi utang maupun 
untuk tidak memperkenankannya diperhitungkan sebagai pengurang besaran penghasilan kena pajak atas sejumlah utang yang dianggap berlebihan, tidak wajar atau yang sering disebut sebagai 'excessive debt' (Blouin, Huizinga, Laeven, \& Nicodème, 2014). Kebijakan interest limitation rule yang berlaku secara umum untuk menilai 'apa yang disebut sebagai excessive' biasanya mengacu pada suatu ambang batas utang terhadap modal (debt to equity fixed ratio). OECD, lewat Proyek Base Erosion and Profit Shifting (BEPS) atau dikenal sebagai BEPS Action Plan mengkritisi sekaligus memberikan rekomendasi mengenai bagaimana sebaiknya ketentuan domestik suatu negara untuk membatasi beban bunga pinjaman didesain. Hal ini tertuang dalam salah satu aksi OECD BEPS yaitu Aksi Empat (OECD, 2015, p. 25). Pemerintah Indonesia juga telah mengadopsi ketentuan terkait pembatasan bunga atas pinjaman baik kepada pihak afiliasi maupun independent dengan menerbitkan Peraturan Menteri Keuangan No. 169/PMK/10/2015 (PMK-169) mengenai Penentuan Besarnya Perbandingan antara Utang dan Modal Perusahaan untuk Keperluan Penghitungan Pajak Penghasilan. Artikel ini akan membahas mengenai berbagai pilihan ketentuan pembatasan utang terhadap modal serta bagaimana penerapan ketentuan perpajakan terkait perbandingan hutang dan modal (debt-to-equity) ratio di Indonesia.

\section{B. Metode Penelitian}

Pendekatan yang digunakan dalam penelitian ini adalah pendekatan kualitatif. Pendekatan kualitatif adalah suatu pendekatan dimana penelitian menekankan pada pengamatan atas suatu peristiwa yang sehingga penelitian tersebut bukan merupakan sebuah penelitian dapat dilakukan di laboratorium konvensional, melainkan harus terjun ke lapangan. Pendekatan ini bertujuan untuk memberikan pemahaman dan interpretasi mengenai suatu fenomena sosial dengan cara observasi secara langsung. Salah satu karakteristik penelitian dengan pendekatan kualitatif adalah tidak bebas nilai, dengan artian dalam proses penelitian dapat dipengaruhi oleh berbagai nilai dan pendapatan subjektif. Lebih lanjut, teori yang digunakan dalam pendekatan ini bukan menjadi hal yang sentral, melainkan hanya sebagai dasar kerangka pemikiran untuk melakukan proses analisa data-data berdasarkan temuan di lapangan. Dengan demikian, teori tidak menjadi bahan verifikasi karena hanya bersifat penunjang dalam proses analisis ketika turun lapangan.

Penelitian ini dilakukan dalam kurun waktu sejak Maret 2017 hingga Mei 2018 dengan lokasi penelitian di Kantor Pusat Direktorat Jenderal Pajak. Apabila ditinjau dari segi tujuan, penelitian ini termasuk dalam penelitian yang bersifat deskriptif. Penelitian deskriptif adalah penelitian yang secara detail menggambarkan fenomena atau gejala sosial yang sedang terjadi. Berkaitan dengan pengertian tersebut, tujuan penelitian ini adalah untuk menggambarkan terkait pelaksanaan ketentuan terkait perbandingan utang terhadap modal dilakukan oleh perusahaan multi nasional di Indonesia, terutama sejak diterbitkannya PMK$169 / 2015$ yang mengatur terkait perbandingan utang dan modal di Indonesia. Teknik pengumpulan data dilakukan menggunakan teknik pengumpulan data kualitatif yaitu melalui studi literatur, studi dokumentasi serta wawancara mendalam. Data yang dikumpulkan terdiri dari data primer dan data sekunder. Data primer terdiri dari interview dengan key informant, sementara data sekunder berasal dari berbagai berbagai informasi publikasi oleh instansi otoritas pajak Indonesia, konsultan pajak dan media massa.

\section{Hasil dan Pembahasan}

\section{Beberapa Pendekatan terkait Ketentuan Pembatasan Utang terhadap Modal}

Perusahaan multinasional dapat memilih membiayai anak perusahaan dengan ekuitas atau utang. Keputusan memilih ekuitas atau pembiayaan utang 
dilakukan melalui rapat pemegang saham (Lüthi, 1991). Dalam konteks perusahaan multinasional (MNEs), perusahaan induk pada umumnya memiliki kebijakan tertentu setelah mengevaluasi aspek perpajakan yang menguntungkan antara negara induk dan anak perusahaan, seperti perlakuan dividen dan bunga, adanya perjanjian penghindaran pajak berganda (Lüthi, 1991). Perusahaan yang aktif secara global memiliki kemampuan dalam mengakses utang dan pasar ekuitas; sehingga tidak ada hambatan dalam penyediaan dana pembiayaan entitas yang dikendalikan. Keputusan dalam pembiayaan intra-grup akan ditentukan oleh bentuk pembiayaan mana yang paling menguntungkan.

Perlakuan perpajakan yang berbeda antara beban bunga dan pembayaran dividen akan mendistorsi struktur modal perusahaan dan menawarkan kemungkinan pengalihan laba melalui pengalihan hutang (Fatica et al., 2012). MNEs dapat mengoptimalkan pembayaran bunga dengan tujuan untuk mengurangi basis pajak dari perusahaan afiliasi yang berada di negara dengan tingkat pajak tertinggi dan memperoleh bunga sebagai pendapatan di perusahaan afiliasi lain yang berlokasi di negara dengan tingkat pajak terendah. Salah satu bentuk skema yang dibuat adalah dengan menjadikan substansi ekuitas dalam bentuk utang, sehingga meningkatkan proporsi utang terhadap ekuitas dan membuat entitas sangat terpengaruh dengan kebijakan pengumpulan modal yang dilakukan. Implementasi aturan thin capitalisation (pengecilan modal) bertujuan untuk mengatasi pembiayaan utang yang berlebihan sesuai dengan tujuan utamanya. Aturan thin capitalisation secara tidak langsung akan mengatur jumlah utang perusahaan sehingga membatasi pengurangan bunga dalam perhitungan basis pajak.

Istilah thin capitalisation belum didefinisikan dengan jelas dalam undangundang pajak. Thin capitalisation pertama kali digunakan oleh otoritas pajak negaranegara anggota OECD untuk menggambarkan kelompok perusahaan multinasional yang membiayai anak perusahaan yang terletak di yurisdiksi dimana tarif pajak tergolong tinggi dengan modal saham minimal dan lebih banyak pembiayaan utang (Gajewski, 2013). Perusahaan dapat dikategorikan sebagai thin capitalisation jika proporsi modal utangnya lebih tinggi dibandingkan dengan modal ekuitasnya (International Bureau for Fiscal Documentation (IBFD), 2005). Istilah lain dari thin capitalisation mengacu pada struktur pembiayaan yang berlebihan, atau transaksi penggerusan laba, dimana MNE yang didanai sebagian besar oleh utang daripada ekuitas (Conlon \& DeConcini, 2000). Istilah ini menunjukkan bahwa aktivitas perusahaan dalam hal pembiayaan utang akan ditunjukkan dalam variasi leverage.

Meskipun tidak jelas dan ditentukan secara tegas oleh hukum, istilah aturan thin capitalisation secara luas diakui dan digunakan dalam diskusi tentang masalah perpajakan terutama dalam hal pengurangan bunga (Gajewski, 2013). Literatur awal menyebut aturan thin capitalisation secara sempit hanya pada rasio utang terhadap ekuitas; namun demikian, literatur terbaru mendefinisikan aturan thin capitalisation dalam pandangan yang lebih luas. Aturan thin capitalisation secara luas diakui sebagai peraturan tentang pengurangan bunga dalam perhitungan penghasilan kena pajak. Beberapa metode telah diperkenalkan dan diterapkan di beberapa negara, walaapun tidak ada yang identik, tetapi secara umum dibagi menjadi tiga jenis pendekatan (1) debt-to-equity ratio; (2) Interest to EBITDA ratio dan (3) Arm's Length Principle (Burnett, 2014; Mooij \& Hebous, 2017).

\section{a. Debt-to-Equity Ratio}

Ketentuan terkait pengaturan rasio utang terhadap ekuitas yang umum digunakan di berbagai negara adalah aturan thin capitalisation. Pada tahun 2016, 49 dari 60 negara dengan aturan thin capitalisation tertentu mengadopsi rasio utang terhadap ekuitas sebagai panduan utama mereka dalam hal 
pengurangan bunga. Gagasan utama rasio utang terhadap ekuitas adalah pembatasan bunga yang dapat dikurangkan dalam kerangka jumlah yang ditentukan utang, baik total atau pihak terkait, dibandingkan dengan ekuitas (Burnett, 2014). Perusahaan hanya dapat mengurangi bunga yang utangnya tidak melebihi proporsi tertentu terhadap ekuitasnya. Sebagai contoh, otoritas pajak suatu negara mengizinkan apabila pembayaran bunga perusahaan atas utangnya dua kali ekuitasnya. Pembayaran terutang yang melebihi utang tidak dapat dikurangkan (Burnett, 2014, pp. 53-54).

Rasio hutang terhadap ekuitas merupakan pendekatan yang paling sederhana. Rasio hutang adalah metode yang paling mudah bagi perusahaan dan otoritas pajak untuk diterapkan dalam penghitungan penghasilan kena pajak. Kesederhanaan menyebabkan biaya lebih murah dengan pengkuran tingkat kepatuhan lebih tinggi (OECD, 2016). Namun, rasio utang terhadap ekuitas juga memiliki kelemahan. Rasio yang saklak tidak mencerminkan realitas ekonomi dan proses bisnis yang dinamis (Traversa, 2013). Sebagai contoh, sektor perbankan dan bisnis jasa keuangan yang pada dasarnya sangat leveraged tidak akan mampu mengatasi leverage yang sangat terbatas. Untuk mengatasi masalah tersebut, negara membuat pengecualian dengan rasio yang berbeda atau mengecualikan bank dan bisnis jasa keuangan dari peraturan yang berlaku umum. Keuntungan lain dari pendekatan rasio utang terhadap ekuitas adalah adanya aturan terkait kepastian besaran yang lebih jelas. Pengurangan bunga di bawah aturan hutang ke ekuitas dapat dengan mudah diprediksi dan direncanakan dengan catatan bahwa suatu perusahaan memiliki kendali atas sumber pembiayaannya. Di sisi lain, kelemahan dari pendekatan rasio utang terhadap ekuitas adalah karena proporsi yang ditetapkan secara tegas, pelaku bisnis cenderung memaksimalkan biaya bunga dan utang mereka hingga rasio utang terhadap ekuitas yang diatur (OECD, 2012).

Beberapa isu lain dari pendekatan rasio utang terhadap ekuitas yang perlu diperhatian yaitu tingkat bunga yang berlebihan (Trepelkov, Tonino, \& Halka, 2015) dan pengalihan utang berjangka waktu (OECD, 2016). Rasio hutang terhadap ekuitas rentan terhadap pengaturan tingkat bunga yang berlebihan dalam hutang antar kelompok. Artinya, meskipun mematuhi rasio utang terhadap ekuitas yang ditetapkan, kelompok masih dapat menguras laba entitas terkendali dengan mengenakan bunga yang lebih tinggi. Tanpa peraturan yang terperinci, perusahaan juga dapat mengalokasikan dan merealokasikan utang dan pembayaran bunga pada entitas yang dikendalikan pada saat pajak pendapatan dihitung (misalnya perusahaan yang dikendalikan "dibanjiri" dengan utang intra-grup dan dibebani pembayaran bunga dari awal tahun fiskal dan membayar atau mentransfer utang tepat sebelum akhir tahun fiskal tersebut hingga proporsi yang diatur dalam rasio utang terhadap ekuitas untuk menghindari kepentingan yang tidak diizinkan).

\section{b. Interest to EBITDA Ratio}

Pendekatan interest to EBITDA ratio sering disebut sebagai pendekatan pelonggaran penghasilan (earning stripping approach), rasio bunga atas EBITDA (Earning before Interest, Tax, Depreciation and Amortization) berfokus pada jumlah bunga yang dibayarkan atau dibayarkan dalam kaitannya dengan jumlah pendapatan terkait bunga tersebut dibayarkan (OECD, 2016). Pada tahun 2016, delapan dari enam puluh negara dengan aturan thin capitalisation tertentu menerapkan bentuk Interest-to-EBITDA 
atau menerapkan aturan terkait potensi penggerusan (Mooij \& Hebous, 2017). Mekanisme rasio Interest-to-EBITDA didasarkan pada persentase tertentu dari penghasilan sebagai jumlah maksimum dari biaya bunga dikurangkan dalam penghasilan kena pajak. Sebagai contoh, jika suatu negara membatasi persentase EBITDA sebesar 30\% dari tahun fiskal tertentu, biaya bunga yang dapat dipotong dalam perhitungan penghasilan kena pajak tahun fiskal tersebut tidak boleh lebih dari 30\% dari tahun yang dilaporkan EBITDA. Jumlah utang dan beban bunga aktual menjadi tidak relevan. Sebagaimana dalam rasio utang terhadap ekuitas (DER), suatu negara juga dapat mengatur terkait perhitungan bunga untuk dikurangi dari total utang atau hanya atas utang yang terkait hubungan istimewa.

Konsep diatas digambarkan dengan ilustrasi sebagai berikut. Misalnya, Negara B dengan tarif pajak penghasilan perusahaan $20 \%$, menerapkan pemotongan bunga sebesar $30 \%$ dari total utang terhadap EBITDA, dan EBITDA Perusahaan Y, depresiasi, amortisasi, dan pembayaran bunga semua utang pada tahun tertentu adalah 250 ribu Euro, 50 ribu Euro, dan 100 ribu Euro. Untuk tujuan pajak, biaya bunga maksimum yang dapat dikurangkan hanya akan menjadi 75 ribu Euro (30\% dari 250 ribu Euro). Penghasilan kena pajak Perusahaan Y menjadi 125 ribu Euro (250 ribu Euro dikurangi 50 ribu Euro dikurangi 75 Euro) dan pajak penghasilan akan menjadi 25 ribu Euro.

Karakteristik Interest-to-EBITDA berkorelasi dengan realitas ekonomi (OECD, 2016). Perusahaan perlu melakukan ekspansi bisnis agar berkembang serta menghasilkan laba, sehingga diperlukan tambahan modal. Apabila pendanaan lewat utang, pinjaman, atau bentuk kewajiban lain dipilih, seyogiyanya hal tersebut dilakukan dalam konteks bahwa perusahaan memiliki kesempatan menggunakan modal tanpa intervensi atau kontrol dari pemberi pinjaman. Hutang atau pinjaman digunakan untuk kegiatan operasional perusahaan untuk produksi, ekspansi atau bentuk investasi lain untuk mendapatkan keuntungan. Oleh karena itu, bunga yang dibayar untuk utang adalah sesuai dengan laba yang dihasilkan oleh perusahaan. Rasio Interest-to-EBITDA bertujuan untuk mencegah pengurangan yang berlebihan yang tidak memiliki korelasi dengan kegiatan bisnis normal, seperti pembebanan utang intra-grup yang pada akhirnya mengakibatkan kerugian pada suatu entitas tertentu.

Namun, pandangan ini mungkin tidak selalu benar ketika perusahaan dalam kondisi yang merugi. Jika perusahaan mengalami penurunan laba atau rugi dari kegiatan bisnis, seperti produksi atau penjualan pada tahun fiskal tertentu serta tidak mendapat pemotongan pembayaran bunga, akan menghadapi konsekuensi tertentu (OECD, 2016). Perusahaan akan mendapat tambahan beban pada perhitungan penghasilan kena pajaknya, karena tidak dapat memperhitungkan pembebanan bunga dan menanggung pajak penghasilan yang lebih tinggi. Perusahaan dalam situasi yang sulit perlu mendapatkan lebih banyak modal untuk menutupi kerugian, namun harus disadari bahwa akan terdapat risiko pembayaran bunga yang semakin banyak yang tidak bisa dikurangkan dalam waktu dekat. Ketergantungan dari pengurangan bunga kepada EBITDA perusahaan yang tidak stabil, membuat aturan pengerusan yang dianggap kurang memberikan kepastian dibandingkan dengan pendekatan lain untuk lingkungan bisnis.

Jerman dianggap berhasil mengimplementasikan rasio interest-toEBITDA dan dapat dianggap sebagai role model untuk pendekatan tersebut. 
Menurut Undang-Undang Pajak Penghasilan Jerman, biaya bunga bersih dapat dikurangkan hingga 30 persen EBITDA perusahaan. Pengukuran dimulai dengan perhitungan beban bunga dan pendapatan bunga, biaya bunga yang tidak melebihi pendapatan dari bunga sepenuhnya dapat dikurangkan. Sementara, jumlah beban bunga yang melebihi pendapatan dari bunga sepenuhnya akan diukur secara proporsional lebih lanjut. Beban bunga termasuk pembayaran bunga dari pinjaman, bunga yang masih harus dibayar, diskon piutang, dan biaya bunga yang diteruskan. Pendapatan bunga termasuk pendapatan bunga dari pinjaman, diskon utang, dan bunga yang masih harus dibayar dari aset modal. Pembayaran bunga sepenuhnya dikurangkan asalkan memenuhi tiga pengecualian: kurang dari 3 juta Euro; perusahaan bukan bagian dari group; atau merupakan bagian dari kelompok yang dikendalikan tetapi rasio ekuitasnya di bawah rasio ekuitas kelompok hingga poin dua persen. Fitur lain dari aturan Jerman adalah bahwa bunga yang tidak dapat dikurangkan dapat diteruskan maksimum lima tahun fiskal berikutnya.

\section{c. Arms' Length Principle}

Prinsip arm's length principle (ALP) dalam pembebanan bunga pada dasarnya menerapkan pengukuran dimana transaksi utang ditentukan oleh mekanisme pasar. Dalam pendekatan ini, utang yang dipertanyakan harus dinilai apakah suatu entitas independen atau pihak ketiga akan memberikan jumlah dan suku bunga yang relatif sama (OECD, 2016). Gagasan terkait pembayaran bunga dengan konsep ini adalah bahwa atas pinjaman intra-grup, pembebanan suku bunga yang dilakukan terlalu rendah atau terlalu tinggi dibandingkan dengan transaksi yang tidak dipengaruhi hubungan istimewa untuk mendapatkan manfaat dari pengalihan utang. Dengan demikian, atas pembebanan bunga perlu dinilai dan disesuaikan berdasarkan nilai dan kondisi pasar.

Karakteristik dari penggunaan pendekatan ALP dibandingkan dengan dua aturan pengurangan bunga sebelumnya adalah bahwa pengukuran yang ditawarkan antara pemberi pinjaman dan penerima peminjam benar telah terjadi atau apakah seharusnya transaksi utang piutang secara ekonomis. Karena menggunakan kekuatan pasar, ALP mewakili proses bisnis dinamis yang dapat memperhitungkan keuntungan yang tidak sama antara utang intra-grup dibandingkan dengan utang pihak ketiga. ALP juga dapat memberikan kepastian yang mendekati rasio utang terhadap ekuitas.

Kekurangan ALP adalah adanya mekanisme penggunaan informasi pasar untuk menetapkan penilaian seolah-olah transaksi terjadi dengan pihak ketiga. Namun, dalam pelaksanaannya, praktek/ penerapan metode ALP dalam menguji pembebanan bunga sangat kompleks. Kesulitan-kesulitan ini meliputi: (i) menemukan transaksi yang sebanding karena karakteristik unik dari bisnis atau proyek kelompok, struktur organisasi kelompok, atau bahwa tidak ada yang akan memberikan hutang kepada entitas atau proyek-proyek selain dari pihak yang terkait, bahkan jika transaksi yang sebanding tersebut ada, upaya untuk memperoleh data dan informasi transaksi juga menimbulkan masalah, (ii) adanya kebutuhan atas keahlian tertentu dalam penilaian risiko bisnis dan pengambilan keputusan keuangan. Penentuan jumlah atau penyesuaian utang atau suku bunga yang dianggap tidak sesuai dengan ALP, sesuai pemilihan metode dan penilaian otoritas pajak dapat menyebabkan sengketa. Dari uraian di atas, terdapat tiga hal yang perlu menjadi catatan terkait kekhawatiran 
dan tantangan penerapan ALP, yaitu pengakuan pihak-pihak terkait, analisis komparatif, dan penentuan utang yang tepat.

\section{Analisis Penerapan Ketentuan Pembatasan Utang terhadap Modal di Indonesia}

\section{a. Perhitungan dan Definisi Utang serta Modal}

Ketentuan terkait pembatasan utang terhadap modal di Indonesia diatur melalui PMK-169. Menurut PMK-169 Pasal 1 ayat 2, utang adalah saldo ratarata utang pada satu tahun pajak atau bagian tahun pajak yang dihitung berdasarkan (i) rata-rata saldo utang tiap akhir bulan pada akhir tahun pajak yang bersangkutan; atau (ii) rata-rata saldo utang tiap akhir bulan pada bagian tahun pajak yang bersangkutan. Alasan utama dipergunakannya rata-rata saldo utang berangkat dari pertimbangan untuk menjaga rasio tersebut sepanjang tahun. Sehingga celah untuk memperbaiki struktur permodalan usaha di akhir tahun untuk tidak melebihi ambang batas semakin berkurang (Wildatunjanah \& Suparningsih, 2019).

Dalam Pasal 1 ayat (3) disebutkan bahwa saldo utang meliputi saldo utang jangka panjang maupun saldo utang jangka pendek termasuk saldo utang yang dibebani bunga. Selain itu, kriteria utang dalam PMK-169/2015 tidak dibatasi hanya kepada utang yang berasal dari pihak afiliasi, namun berlaku secara umum.Walau terkesan memberatkan, namun definisi utang yang berlaku umum tersebut pada hakikatnya dapat mencegah skema back to back loan.

Demikian halnya dengan perhitungan saldo modal definisi saldo modal meliputi ekuitas sebagaimana dimaksud dalam standar akuntansi keuangan yang berlaku (Pasal 1 ayat 5). Mengacu pada PSAK No.21 tentang akuntansi ekuitas, ekuitas merupakan bagian hak pemilik dalam perusahaan yang pada dasarnya berasal dari investasi pemilik dan hasil usaha perusahaan yang terdiri atas setoran pemilik yang seringkali disebut modal atau simpanan pokok anggota untuk badan hukum koperasi, saldo laba, dan unsur lain. Oleh karena itu, ekuitas akan berkurang terutama dengan adanya penarikan kembali penyertaan oleh pemilik, pembagian keuntungan atau akibat kerugian (Efendi \& Wibowo, 2017).

Dari ayat yang sama, disebutkan pula bahwa pinjaman tanpa bunga dari pihak yang memiliki hubungan istimewa dikategorikan sebagai ekuitas. Penggolongan ini tampaknya ingin mengeliminir adanya penyertaan modal yang berkedok sebagai utang, atau bersifat hybrid financial instrument (Seminogovas, 2015). Perbedaan perlakuan pajak antara beban bunga dan dividen jelas mendorong induk perusahaan atau pemilik saham untuk menyertakan modal (substansi) menjadi seolah-olah memberikan pinjaman (secara legal). Salah satu ciri dari penyertaan modal adalah tidak adanya pembayaran return secara rutin, seperti halnya pada pinjaman (Johannesen, 2014). Walau demikian, penting untuk diperhatikan bahwa klausul ini bertabrakan dengan Peraturan Pemerintah Nomor 4 Tahun 2010 tentang Perhitungan Penghasilan Kena Pajak dan Pelunasan Pajak Penghasilan dalam Tahun Berjalan (selanjutnya PP No.94/2010), terutama Pasal 12 ayat (1). Pasal tersebut memperbolehkan bahwa pinjaman tanpa bunga diperkenankan apabila berasal dari dana pemegang saham yang tidak dalam keadaan merugi dimana seluruh modal yang seharusnya disetor oleh pemegang saham. Selain itu, penerima pinjaman sedang mengalami kesulitan keuangan untuk kelangsungan usahanya. 


\section{b. Ketentuan Rasio 4:1}

PMK-169/2015 mengatur bahwa besarnya perbandingan antara utang dan modal untuk keperluan perhitungan Pajak Penghasilan ditetapkan paling tinggi sebesar empat banding satu (4:1). Pada dasarnya sangat sulit untuk menentukan struktur utang terhadap modal yang dirasa 'tepat' yaitu struktur yang benar-benar dapat menjamin realitas bisnis di satu sisi dan pembatasan besaran biaya bunga di sisi lain. Jika penentuan DER diletakkan dalam upaya menjamin realitas bisnis, maka terdapat kesulitan dalam penentuan rasio. Selain itu, hal ini juga memberikan beban administrasi yang tinggi bagi otoritas pajak untuk memastikan bahwa rasio tersebut telah cukup layak bagi masing-masing sektor usaha atau masing-masing entitas (wawancara dengan ahli). Namun, disisi lain, kenyataannya banyak negara yang memperbolehkan rasio yang lebih tinggi bagi industri jasa keuangan dibandingkan dengan sektor usaha lainnya. Hal ini didasarkan pada pertimbangan bahwa asset dari lembaga-lembaga tersebut biasanya lebih liquid dan mempertimbangkan bahwa pelaku usaha jasa perbankan berfungsi sebagai intermediary di pasar keuangan yang mana aktivitas mereka adalah menyediakan pinjaman (Barnes, 2013, p. 12).

Namun, hingga saat ini masih terus dilakukan studi untuk mengetahui apakah untuk konteks sturktur permodalan bagi sektor privat di Indonesia rasio 4:1 yang ditetapkan dalam PMK-169/2015 ini telah tepat. Hingga saat ini, jawaban atas pertanyaan tersebut masih sangat relatif. Jika rasio tersebut dibandingkan dengan rata-rata yang ada di negara lain, yaitu $3: 1, \quad$ sepertinya PMK-169/2015 memberikan kelonggaran yang memberikan ruang bagi Wajib Pajak untuk memiliki pinjaman lebih besar dalam struktur permodalan mereka. Jika melihat kebijakna ini dari sisi positif, dapat dikatakan bahwa sepertinya pemerintah ingin memiliki ketentuan yang juga tidak menghambat ekspansi usaha, seperti yang pernah menjadi alasan penangguhan KMK-1002/1984. Meskipun demikian, tidak diketahui dengan pasti alasan dan pertimbangan valid mengenai penentuan resio 4:1 yang berlaku saat ini.

PMK-169/2015 mengecualikan beberapa Wajib Pajak dari ketentuan perbandingan (Pasal 4), yaitu: (1) Wajib Pajak bank; (2) Wajib Pajak lembaga pembiayaan; (3) Wajib Pajak asuransi dan reasuransi; (4) Wajib Pajak yang menjalankan usaha di bidang pertambangan minyak dan gas bumi, pertambangan umum, dan pertambangan lainnya yang terikat kontrak bagi hasil, kontrak karya, atau perjanjian kerjasama pengusahaan pertambangan, dan dalam kontrak atau perjanjian dimaksud mengatur atau mencantumkan ketentuan mengenai batasan perbandingan antara utang dan modal; dan (5) Wajib Pajak yang atas seluruh penghasilannya dikenai Pajak Penghasilan yang bersifat final berdasarkan peraturan perundangundangan tersendiri; dan (6) Wajib Pajak yang menjalankan usaha di bidang infrastruktur.

Pasal ini menyiratkan beberapa hal penting: (i) bahwa tiap-tiap kegiatan usaha dari masing-masing pelaku bisnis pada dasarnya tidak dapat dipersamakan dari struktur permodalannya; (ii) bahwa terdapat jenis-jenis industri yang sifat permodalannya harus fleksibel terutama untuk infrastruktur karena sifatnya yang strategis; (iii) ketentuan tunduk pada peraturan yang bersifat lex specialis seperti halnya pada kontrak karya pertambangan; dan (iv) menghindari adanya pemajakan berganda untuk Wajib Pajak yang telah dikenakan pajak penghasilan yang bersifat final. 


\section{c. Pelanggaran atas Rasio}

Pelanggaran atas rasio perbandingan antara utang dan modal sebesar 4:1 akan menyebabkan biaya pinjaman yang berada di atas rasio tersebut tidak dapat menjadi pengurang penghasilan kena pajak seperti yang diatur dalam PMK-169/2015. Biaya pinjaman sebagaimana dimaksud pada Pasal 3 ayat (1) adalah biaya yang ditanggung Wajib Pajak sehubungan dengan peminjaman dana yang meliputi: (a) Bunga pinjaman; (b) Diskonto dan premium yang terkait dengan pinjaman; (c) Biaya tambahan yang terjadi yang terkait dengan perolehan pinjaman (arrangement of borrowings); (d) Beban keuangan dalam sewa pembiayaan; (e) Biaya imbalan karena jaminan pengembalian utang; dan (f) Selisih kurs yang berasal dari pinjaman dalam mata uang asing sepanjang selisih kurs tersebutsebagai penyesuaian terhadap biaya bunga dan biaya sebagaimana dimaksud pada huruf $b, c$, d, dan e.

Dari kriteria biaya pinjaman di atas terlihat bahwa PMK-169/2015 mengacu pada gross interest expenses karena tidak mempertimbangkan jumlah pembayaran bunga yang diberikan dari pihak lain. Walau demikian, definisi yang berlaku luas tersebut juga didukung oleh OECD yaitu biaya pinjaman juga mencakup seluruh pembayaran keuangan yang dapat dipersamakan dengan bunga. Pembayaran keuangan yang dapat dipersamakan dengan bunga yang dimaksudkan adalah seluruh pembayaran yang terkait dengan kegiatan pembiayaan dari Wajib Pajak dan ditentukan dalam bentuk persentase (baik fixed maupun variable) dari pokok. Selain itu, segala biaya yang dikeluarkan dalam untuk pembiayaan juga harus dipertimbangkan, misalkan biaya imbalan dan arrangement fees (OECD, 2015).
Selain itu, jika saldo ekuitas sama dengan atau kurang dari nol, maka seluruh biaya pinjaman tidak dapat diperhitungkan dalam perhitungan penghasilan kena pajak seperti yang diatur dalam PMK-169/2015, Pasal 3 ayat (4). Hal ini berarti bahwa tidak akan ada pinjaman yang bisa dibiayakan sebagai pengurang pajak jika perusahaan tersebut tidak memiliki ekuitas sama sekali. Pada dasarnya ini merupakan refleksi yang terjadi pasar terbuka, di mana tidak terdapat pihak ketiga yang 'mau' untuk memberikan pinjaman karena perusahaan tanpa ekuitas akan memiliki credit worthiness yang rendah. Dengan demikian, pinjaman yang didapatkan tanpa adanya ekuitas dapat indikasi penyertaan modal secara terselubung.

\section{d. Pinjaman dari Hubungan Istimewa}

Biaya pinjaman atas utang kepada pihak yang memiliki hubungan istimewa harus pula memenuhi prinsip kewajaran dan kelaziman usaha sebagaimana dimaksud dalam ketentuan Pasal 18 ayat (3). Hal ini berarti memisahkan antara dua persoalan: struktur modal yang dianggap 'wajar' dan suku bunga yang wajar (transfer pricing rule). Dengan demikian, hadirnya PMK-169/2015 justru menjawab keraguan mengenai tahapan analisis transfer pricing atas pinjaman internal yang selama ini dilakukan. Pada praktik di lapangan, seringkali analisis kewajaran pinjaman internal (dengan menggunakan kerangka analisis arm's length principle) juga menyertakan analisis kewajaran transaksi yang salah satunya melibatkan telaah atas perbandingan rasio utang terhadap modal. Dalam praktik, rasio yang sering dijadikan acuan adalah 3:1. Adanya ketentuan DER ini jelas akan memberikan batasan bahwa analisis transfer pricing atas pinjaman internal 
akan lebih berkaitan dengan besaran "suku bunga yang wajar".

Wajib Pajak yang mempunyai utang swasta luar negeri, wajib menyampaikan laporan besarnya utang swasta luar negeri tersebut kepada Direktur Jenderal Pajak (Pasal 5 ayat (1)). Jika tidak melaporkan maka biaya pinjaman yang terutang dari utang swasta tidak dapat dikurangkan untuk menghitung penghasilan kena pajak. Tata cara pelaporan besarnya utang swasta tersebut nantinya akan diatur lebih lanjut dalam PerDirjen.

\section{Ketentuan Thin Capitalisation di Australia}

Perubahan yang signifikan tentang Thin Capitalisation Rules di Australia terjadi pada bulan Juli tahun 2001. Hal ini pula yang menjadi pertimbangan yang menjadikan Australia sebagai negara yang dijadikan salah satu pokok bahasan dalam studi ini, dimana ketentuan thin capitalization rule telah diterapkan sejak awal tahun 2000 an. Ketentuan baru ini menolak debt deductions atas dana yang dipinjam dari shareholders ("controllers") jika debt to equity rationya berlebihan. Ketentuan ini berlaku baik untuk foreign controlled Australian Companies, Branch or Associates (inbound) maupun Australian Entities that control foreign entities atau operate abroad through Permanent Establishment (outbond). Dalam penerapan ketentuan ini sebuah entitas harus dikategorikan dalam salah satu dari delapan kategori entitas tersebut, dimana setiap kategori entitas memiliki ketentuan tersendiri (Australian Tax Office, 2016).

Debt Equity Ratio (DER) diterapkan untuk seluruh hutang termasuk related party foreign debts dan third party debts. Termasuk yang dikenakan dalam penerapan DER ini adalah perjanjian dimana suatu entitas (termasuk asosiasinya) menerima dana tanpa adanya kewajiban untuk membayar kembali jumlah yang sama atas dana yang dinvestasikan tersebut. Jika jangka waktu pembayaran kembali melebihi
10 tahun maka jumlah dana yang diinvestasikan di diskonto untuk memperoleh present value investasi tersebut. Sedangkan yang dapat diperhitungkan sebagai modal termasuk paid-up value of shares dan share premium pada akhir tahun, serta opening retained earnings dan assets revaluations aktiva yang dimiliki. Reedemable preference shares dan participating or convertible debt tidak termasuk dalam definisi hutang tetapi diperhitungkan sebagai modal, demikian juga dengan interest free debt tidak termasuk sebagai modal (Kayis-Kumar, 2015)

Berdasarkan safe harbour rules, interest deductions dibatasi oleh Debt to Equity Ratio in excess of $75 \%$ (Debt Equity 3:1), dan menjadi subject to arm's length test. Selain itu, biaya bunga juga tidak dapat dikurangkan sebagai biaya jika The Australian operation melebihi 120\% of worldwide ratio group. The worldwide gearing test ini hanya diterapkan jika Australian Debt Entity tidak dikendalikan oleh perusahaan asing. Penghitungan rasio menggunakan rata-rata foreign debt sepanjang tahun dibandingkan dengan modal yang dimiliki. The excess interest dan related financial charges ("debt deductions") tidak dapat dibebankan sebagai biaya namun tidak di-recharacterised sebagai dividend. Australia memberlakukan ketetentuan tersendiri bagi financial institutions (Kayis-Kumar, 2016).

\section{Simpulan}

Dampak negatif dari penggunaan utang yang berlebihan dalam struktur permodalan perusahaan serta fakta bahwa tarif $\mathrm{PPh}$ Badan Indonesia yang relatif tinggi; maka ketentuan mengenai interest limitation rules sangatlah diperlukan. Adanya PMK169/2015 diperkirakan akan dapat mengubah perilaku perusahaan (terutama multinasional). Hal ini juga telah didukung dengan fakta bahwaketentuan serupa telah berhasil mengurangi pinjaman internal serta mengubah keputusan pembiayaan usaha. 
Meskipun demikian, terdapat beberapa hal yang harus dicermati dalam PMK169/2015 ini, sebagai berikut: Pertama, ketentuan interest limitation rule yang berbentuk perbandingan utang terhadap modal pada dasarnya sangat tepat diterapkan di negara berkembang terutama karena lebih mudah dalam administrasinya. Walau demikian, ketentuan ini juga bersifat subjektif karena tidak mempertimbangkan fakta bisnis. Wajib Pajak yang perbandingan utang dan modalnya melebihi 4:1 masih memiliki kesempatan bahwa biaya pinjaman akan menjadi pengurang penghasilan kena pajak selama dapat membuktikan bahwa rasio utang terhadap modalnya wajar (ALP) jika dibandingkan dengan perusahaan lain sejenis.

Kedua, definisi utang yang ditetapkan lewat peraturan ini sudah tepat. Berkaitan dengan perhitungan dilakukan dari rata-rata saldo utang akhir bulan sehingga dapat mencegah upaya merestrukturisasi permodalan hanya di akhir tahun untuk mematuhi rasio yang ditetapkan. Selain itu, utang tidak dibedakan hanya terbatas pada utang yang dilakukan oleh pihak yang memiliki hubungan istimewa sehingga juga tetap dapat mencegah skema back to back loan. Terakhir, pinjaman tanpa bunga dari pihak yang memiliki hubungan istimewa akan secara otomatis dianggap sebagai ekuitas. Hal ini penting untuk mencegah praktik hybrid financial instrument. Walau demikian, ketentuan ini bertentangan dengan PP-94/2010 Pasal 12 dan membutuhkan penjelasan lebih lanjut.

Ketiga, pelanggaran atas batasan rasio 4:1 akan berakibat pada besaran biaya pinjaman yang dapat menjadi pengurang penghasilan kena pajak. Hal ini sudah sesuai dengan international best practice. Selain itu definisi biaya pinjaman yang luas dalam PMK-169/2015 ternyata juga sudah sesuai dengan rekomendasi OECD. Keempat, adanya ketentuan ini memberikan penegasan tentang bagaimana analisis pinjaman internal (yang dilakukan dengan pihak yang memiliki hubungan istimewa) harus dibedakan antara kerangka transfer pricing dan interest limitation rule. Walau demikian, keduanya saling melengkapi seperti halnya penerapan di Australia. Kelima, ketentuan DER di Australis dengan rasio 3:1 hanya membatasi pengurangan interest, dan dalam pengujian kewajaran ALP, apabila terdapat excess interest akan direkarakterisasi sebagai dividen.

\section{DAFTAR PUSTAKA}

Australian Tax Office. (2016). Thin Capitalisation. Retrieved January 12, 2020, from https://www.ato.gov.au/Business/Thincapitalisation/

Barnes, P. A. (2013). Limiting Interest Deduction and Other Financial Payments. In Papers on Selected Topics in Protecting the Tax Base of Developing Countries (p. 12). New York: United Nations Department of Economic and Social Affairs United Nations Secretariat.

Blessing, P. H. (2012). The Debt-Equity Conundrum - A Prequel. Bulletin for International Taxation, 66(4/5), 200.

Blouin, J., Huizinga, H., Laeven, L., \& Nicodème, G. (2014). Thin capitalization Rules and Multinational Firm Capital Structure. CEPR Discussion Paper No. 9830, 1-2.

Burnett, C. (2014). Intra-Group Debt at the Crossroads: Stand-Alone Versus Worldwide Approach. World Tax Journal, 6, 53-54.

Conlon, R., \& DeConcini, G. (2000). Thin Cap: US. Choose your instruments carefully. International Tax Review, 27, 27.

Efendi, A. F. W., \& Wibowo, S. S. A. (2017). Pengaruh Debt to Equity Ratio (DER) dan Debt to Aset Ratio (DAR) terhadap Kinerja Perusahaan di Sektor Keuangan yang Terdaftar di Bursa Efek Indonesia. Journal of Applied Managerial Accounting, 1(2), 157-163. 
Fatica, S., Hemmelgarn, T., \& Nicodeme, G. (2012). The Debt-Equity Tax Bias: Consequences and Solutions. EC Taxation Papers No. 33, 3-4.

Gajewski, D. (2013). Tax-Related And Economic Consequences Of Selecting The Method Of Debt Financing Of Companies With Regard To Thin Capitalisation In OECD Member Countries. Contemporary Economics, 7, 78.

International Bureau for Fiscal Documentation (IBFD). (2005). International Tax Glossary (4th ed.). IBFD.

Johannesen, N. (2014). Tax Avoidance with Cross-border Hybrid Instruments. Journal of Public Economics, 112, 40 52.

Kayis-Kumar. (2015). Taxing Cross-border Intercompany Transactions: Are Financing Activities Fungible? Australian Tax Forum, 30(3), 627-661.

Kayis-Kumar. (2016). What's BEPS got to do with it? Exploring the effectiveness of thin capitalization rules. EJournal of Tax Research, 14(2), 359-386.

Lüthi, D. (1991). Thin Capitalisation of Companies in International Tax Law. Intertax, 10, 446 .

Masui, Y. (2014). Interest Deduction, Corporate Groups and Tax Jurisdictions - A Hitchhiker's Guide to an Aspect of the BEPS Project. Asia Pacific Tax Bulletin, 103 - 105.

Mooij, R. de, \& Hebous, S. (2017). Curbing Corporate Debt Bias. IMF Working Papers, 17, 6.

OECD. (2012). Thin Capitalisation Legislation a Background Paper for
Country Tax Administrations (Pilot Version for Comments). Paris: OECD Publishing.

OECD. (2015). Limiting Base Erosion Involving Interest Deductions and Other Financial Payments, Action 4 2015 Final Report, OECD/G20 Base Erosion and Profit Shifting Project. Paris: OECD Publishing.

OECD. (2016). Limiting Base Erosion Involving Interest Deductions and Other Financial Payments, Action 4, 2016 update: Inclusive Framework on $B E P S$. Paris: OECD Publishing.

Piltz, D. J. (1996). General Report (1996), Subject II: 'International Aspects of Thin Capitalization', Cahier de droit fiscal international (LXXXIb). The Hague: Kluwer Law International.

Seminogovas, B. (2015). Taxation of Hybrid Instruments. Procedia - Social and Behavioral Sciences, 213, 299-303.

Traversa, E. (2013). Interest Deductibility and the BEPS Action Plan: nihil novi sub sole? British Tax Review, 5, 611.

Trepelkov, A., Tonino, H., \& Halka, D. (2015). United Nations Handbook On Selected Issues In Protecting The Tax Base Of Developing Countries (1st ed.). United Nations.

Wildatunjanah, E. S., \& Suparningsih, B. (2019). The Effect of Debt to Equity Ratio and Pricer Earning Ratio on Stock Price with Moderating as BI Rate Variable in Retail Sector Companies Listed in Indonesia Stock Exchange (IDX). East African Scholars Journal of Economics, Business and Management, 2(6), 307-317. 